\title{
The Written and Unwritten Worlds of Marcovaldo and Calvino
}

\author{
To see a world in a grain of sand \\ And a heaven in a wild flower \\ Hold infinity in the palm of your hand \\ And eternity in an hour.
}

Auguries of Innocence, William Blake

With increasing frequency through the course of his writing career, in his essays, interviews and occasional articles, Calvino described the substance of his critical perceptions of the challenging but frustrating relationship between the writer and the world. On the occasion of one lecture, entitled "The Written and the Unwritten Word," he spoke specifically to one aspect of this relationship, adopting one of his typically contrastive paradigms with reference to the "discontinuity between the written page, fixed and settled, and the moving multiform world outside the page" (38-39). His consideration centered on this description by way of definition of the writer's goals and perspective, adding the further statement that the great writers are those who succeed in conveying to the reader an approach to, rather than an arrival at knowledge and thus give a precise feeling of knowledge that cannot be found elsewhere. The writer always writes about things that he does not "know," according to Calvino; therefore he writes to give the unwritten word and world a channel of self-expression through him. "Yet," he continues, "the moment my attention wanders from the settled order of the written lines to the movable complexity no sentence is ever able to hold entirely. I come close to understanding that on the other side of the words there is something words could mean." From the point of view of the reader, admiration focuses on those writers who "have built up in their works a world we feel as most meaningful, opposing it to a world they too felt lacking in meaning and perspective." Calvino definitely eschews through this dichotomy the currently popular and often exclusively hermeneutic and exegetical role of the writercritic. This is one among the many ways in which this approach manifests the early influence of the poetics of Neo-Realismo, its questioning and open-ended stance reflective of one of the prime pedagogical techniques used by severa! of the major writer-critic practitioners of Neo-Realism, and most particularly by Vittorini and Pavese, as well as by the contemporaneous Hermetic poets. 
Calvino's dilemma-man's dilemma - is that while he can find satisfaction, clarity, comfort, and control within books, in the already written word and world, he finds no such satisfaction in the wider world where all activ. ity defies prediction, or any form of ultimate clarification. This simple but overwhelming fact establishes several of the most functional parameters of Calvino's poetics. He finds himself constrained again and again to "choose a strategy for facing the unexpected without being destroyed by it" ("The Written and the Unwritten Word" 38). A prime strategy in the service of this end is already in place, constituted by his cxpress belief that language is a basic form of knowledge.' This vicw, which ultimately unshackles language from its traditionally viewed function as a mere tool of the creative process, has further timely implications, reaffirmed by many of his contemporaries, elegantly so in the recent statement by Joseph Brodsky: "For, while always older than the writer, language still possesses the colossal centrifugal energy imparted to it by its temporal potential, that is, by all time lying ahead" (Address). Consectary in any logical scheme derived from this belicf, it follows that language as a basic form of knowledge is endowed with the same solidity and mass as is any other reality, when and as expressed by the writer. It also follows that such knowledge always implies its own ability to expand like a temporal Janus geminus; its limits are unbounded. Not only does the opaque or undecipherable reality of the world offer resistance as it spirals outward, but also the repertory of "pre-words," the sources and the storehouse of the imagination, ideas and combinations of ideas that have not yet been given substance and, therefore, the status of knowledge, through language. Both Calvino and Brodsky speak to the past and future of literary expression in terms of this same temporal continuum. Their literary context may differ through their choice of genre; nevertheless, they both recall the Neo-Realists' insistence on the unitary nature of living phenomena, all contained by their cyclical rhythms and ultimately determined by those rhythms. (The simple expedient of using seasonal categories as the organizing frame for the collection, Marcovaldo ov'vero le stagioni in città, 1963, is one of Calvino's many gestures in these stories to this truth.) If the language of external reality - the unwritten world-were to merge with the written world (Calvino suggests that this is the goal sought by some writers through a process of mimesis), no further reconciliation between the two would be necessary.

Yet, this solution will not satisfy Calvino after his experience of NeoRealism and the unsettling events of the two previous decades of Italian socio-economic, political and cultural life. He pursues a different course: "The true challenge for a writer is to speak about the tangled mess of our century using a language so transparent that it reaches a hallucinatory level, as Kafka did" (Stille 39). Here, too, the poetics of Neo-Realismo, most pointedly articulated by Vittorini in his attempts to create a new attitude toward "la formazione del 'genere" "(251), informs Calvino's statement that language is a form of knowledge, and implies the humanistic aim that is inherent in his 
statement. Thomas Sutcliffe expresses a similar idea when he suggests what might well be Calvino's enjoyment of the "suppositional etymology which derives the word narrative from the Latin gnarus - knowing or skilled" (921). Narration, in whatever form it has traditionally assumed-from its roots in an oral tradition, the fable and the epic, to modern prose fiction and poetry is what allows the writer possession of knowledge. It is Calvino's "fixed and settled page," or what Brodsky refers to as "the acceleration of conscience, of thinking, of comprehending the universe."

One easily recognizable and fundamental principle in Calvino's endeavor to comprehend, and a further indication of his patent debt to the Neo-Realists, is affirmation of the combinatory process that he adopts to establish multiple levels of "knowledge" in his writing. A functional critical stance constitutes always and foremost a radiating spectrum of highlights woven into the fabric of the narrative itself. Integrated throughout the twining threads of the characters' every action, the critical stratum is ultimately necessary to both the warp and woof of that fabric in order to evoke both the writer's and reader's creation and interpretation of the text. This is often announced in a manner similar to that adopted by Vittorini and Pavese. Two typical and dramatic examples appear in the first paragraphs of Vittorini's Conversazione in Sicilia and Pavese's La casa in collina, the polemic incisiveness of which is in no way diluted or mitigated by the lyric quality that animates both presentations. Marcovaldo ovvero le stagioni in città offers the first and parallel example among Calvino's novels. It follows this same pattern, introducing the critical bases of the entire work embedded in an early paragraph of the first of the twenty stories, "Funghi in città." 2 In his introduction to the volume, written for the 1966 edition in the series, Letture per la scuola media (the individual stories having been written during the preceding ten-year period), Calvino indicates that the misadventures of Marcovaldo begin at the moment when "la grande ondata 'neorealista' già accenna al riflusso," and that his experiment with this type of modern fable, "di divagazione comico-melancolica," resides "in margine al "neorealismo" (10). At the same time, although the subject matter of Neo-Realism may now risk becoming a literary cliché, in Calvino's judgement it is no less pressing as a contemporaneous reality than it had been some twenty years earlier when the first dramatic statements of the Neo-Realist ethic appeared. Poverty, a central concern of Neo-Realism, simply has changed and expanded its locus from the rural environment to the large industrial centers. There the economic miracle still eludes the masses who have been pushed aside and discarded in favor of themes that focus instead on production and consumption. Now, as a result, "le favole ironicomelancoliche di Marcovaldo ... si situano in margine a questa letteratura sociologica" (10).

Marcovaldo also illustrates Calvino's early approach to the creation of interrelated levels of narrative reality that challenge the "hallucinatory" without being destroyed by it. These levels are suggested through a series of 
transformational possibilities, the first of which is iterated by the positing of a new beginning in each of the separate episodes, but it is a beginning that has no immediate temporal relationship to the stories that precede or follow, other than through the rubrical progression of seasons. A series of possibly related texts is then doubly suggested through the presence of the same comic protagonist and the indication of this scasonal framework. Yet, there is also a disjointed aspect to Marcovaldo's adventures; the titles-Spring, Summer, Autumn, Winter - are as misleading as they are categorical. The reader may err if he assumes a chronological sequence associated with the single episodes since it is quite clear in the ages of Marcovaldo's children from one episode to the next that the stories are discontinuous. Implied chronological order is thus simply a possible signifier of form, an attempt to contain the hallucinatory. This device anticipates the correlative that Calvino will later introduce to link the several chapters of Se una notte d'inverno un viaggiatore where the reader is challenged at the beginning of each new chapter to readjust his perception on a Barthesian model of possible intertextual causalities.

Anticipating also the unsatisfying or unresolved conclusions to the stories of $T$ con zero, Marcovaldo's incubus is the same at the beginning of each adventure as it is at the end. He is caught in the same temporal and spatial frame, having outdistanced time and space through fantasy, but he has moved ahead neither an inch nor a moment. His incubus absorbs infinite levels of displacement but it does not change as he is forced to engage in the challenge eternally with his meager arsenal of weapons. Even the specifics of this arsenal are sketchy at most. Having been established by his creator as vaguely non-urban in his orientation to the world if not in his recent origins, he must face not only the trauma of adjustment to the city ambient, for which he is ill-suited, he must confront as well the persistent and gnawing elementary needs that are a direct result of his lack of any skills whatever and thus constantly threaten his own survival and that of his large family. How does Marcovaldo face the unexpected without being destroyed by it? In the introduction, Calvino offers a partial answer: his protagonist's stolid obstinacy and his enduring non-resignation. These, however, as Calvino himself says, are only attitudes. Attitudes may be shaped by experience and convictions; they may change as experiences and convictions change. Marcovaldo's ideas seem to undergo no change or modification or any signs of conspicuous growth of consciousness, not even intuitions of new and different forms of awareness. Yet, there is something more than mere obstinacy deep within that affective part of Marcovaldo's nature that is genetically and thus unswervingly geared to survival. Obstinacy and non-resignation are external trappings, signals of the unwritten world that Marcovaldo can express in no other way than through his incoherent and awkward gestures, through his probing of what seems always to him a viscous, unscizable reality.

Survival draws Marcovaldo back again and again from the abyss of the hallucinatory, making him not only obstinate but also resilient and adaptable. 
This is the unspoken lesson that his children learn from him, just as he, on occasion, learns it from his children, despite the difference between their easy acceptance and adaptation to city ways and Marcovaldo's interminable and unsuccessful struggle to comprehend those ways. "Il bosco sull'autostrada" illustrates this point, beginning with its melancholic ternary description of Marcovaldo and his family huddled before the pitifully waning warmth of the stove, in the sadly humorous tour de force that assigns each family member an emblematic characteristic in the format of a comic strip with its hovering balloons. ${ }^{3}$ Significantly, this is the single story in the collection in which Marcovaldo does emerge successful in his quest (relatively, because Calvino pointedly tells the reader that the pressed material of the billboards burns only too quickly). The near-sighted policeman, Astolfo, rides away, smug in his self-esteem for having interpreted the billboard's message, as he leaves Marcovaldo perched precariously on the billboard but finally if only momentarily victorious in his battle against the winter cold. As the moonlight intensifies, we hear with Marcovaldo the harsh but satisfying muted sound of the saw grating against the wood of the billboard.

The harmonious and flowing motion of things in nature, the effortless solidity of their essence, are Calvino's touchstones. When man is introduced on the scene, and with him the often unnatural and aimless acts of violence or aggression, or even natural gestures of his need to tame nature, Calvino's very vocabulary exhibits the signs of this dualism. From the inherent strength of vigorous spontaneity and certainty of being, the images shift to reflect intimations of discord and uncertainty, most often in the area of sensory imagery. The "gracchiare" of Marcovaldo's saw, like the "scorrere garrulo" of the fountain (26), and the "ronzio . . come un raschio interminabile" (25) in "Villeggiatura in panchina," the "cigolo" (36) of the wheelbarrow that Serenella rides as Giovannino pushes it, and the deep, alarming reverberation of the gong, in "Il giardino incantato" (I racconti 34-38), even Biagio's writing, "zeppo di cancellature, di rimandi, di sgorbi nervosi, di macchie, di lacune," in the final paragraph of Il barone rampante, reflect the stridency and skirling, the imbalance, and the ill-meshed gearing that man introduces into the universe (I nostri antenati 406). Yet, these dissonances are also the emblem of man's liberty, of his striving for forms of expression that are uniquely his. They are his ongoing apocalypse of endurance, often his only way to rewrite the world.

There are other lessons for the reader as well as for Marcovaldo and his children in the game that Calvino is constantly playing with him and with them. One clue to playing the game successfully in Marcovaldo resides in ferreting out the structural formulae that Calvino imposes throughout the work. When applied to the individual stories, they reveal one of the unitary patterns of the stories. There is a moment of transition in each episode when the dulled and desperate adult and modern fantasy that constitutes the framework is lifted away to reveal the bare emotions and drives that lie further 
below the surface. As the first lantasy is swept away and disappears, it is replaced by another and more primitively fabulous burst of imagination. The hallucinatory is displaced, in favor of deeper-seated tensions that do allow for simple survival, a survival which may be precarious but is nonetheless a stronger implosive force on Marcovaldo's psyche than the nightmarish quality of his existence. This tension, not the expected and usually very real échec, is what nurtures Marcovaldo's resistance and endurance.

"Marcovaldo al supermarket" is a prime example. Calvino refers in the introduction to its symbolic image (10), an evening's amusement for Marcovaldo and his family "window shopping" through the supermarket with no intention of purchasing anything as they have no money. In the role of pater familias, Marcovaldo admonishes the children to touch nothing, but he himself cannot resist the abundant riches of the supermarket aisles. He succumbs as do they. He takes a shopping cart, moves through the aisles, randomly selecting items, filling the cart, while avoiding at every turn the other members of his family, each of whom, independently and unbeknownst to the others has done the same. Marcovaldo staves off as long as he can an inevitable dissolution of his fantasy which is represented by the broad cmpty area at the front of the store, and the menacing cash register looming directly beyond.

Two separate moments fix the substance and significance of the transformation that takes place during this fantastic adventurc. The first is associated with the mesmerizing effect that this sudden abundance has on Marcovaldo, feeding his desire to play out the fantasy to the fullest:

I suoi passi lo portavano ad addentrarsi in reparti meno frequentati; i prodotti dai nomi sempre meno decifrabili crano chiusi in scatole con figure da cui non risultava chiaro se si trattava di concime per la lattuga o seme di lattuga o di lattuga vera e propria o di veleno per i bruchi della lattuga o di becchime per attirare gli uccelli che mangiano quei bruchi oppure condimento per l'insalata o per gli uccelli arrosto. Comunque Marcovaldo ne prendeva due o tre scatole. (110)

Marcovaldo's desire for things that he knows he cannot have spurs him to take everything indiscriminately, even items he does not recognize, while it allows Calvino the opportunity to display his inventiveness in one of his typical clustered images that stretches abundance beyond hallucination in order to control it rather than be absorbed by its intensity (see Olken 105108). The need to give vent to his overwhelming desires through this fantasy is the same need that he cxpresses in the first story, "Funghi in città," when he refuses to tell even his children the location of the mushrooms for fear that they might tell others, thereby reducing the crop that will be available for him and the family.

The second moment of transformation occurs when the fantasy threatens to turn ugly. There is the exit at every turn, "dove una cassiera di sentinella puntava una macchina calcolatrice crepitante come una migliatrice contro 
quelli che accennavano a uscire" (112). Images of "bestie in gabbia" and "carcerati in una luminosa prigione dai muri a pannelli colorati" (112) complete the threat and increase Marcovaldo's anxiety. And then, Open, Sesame! A miraculous path of escape presents itself in the shape of a black hole in one of the walls, into which Marcovaldo, Domitilla, and the five children pass in orderly procession, each still pushing his heavily laden shopping cart. The fantasy becomes mythic but it is a myth that accommodates both a timeless and a modern world. The portentous black hole of astronomical speculation appears to these newly arrived explorers and unexpectedly spreads out before them a star-studded sky. It contains other illumination as well: sparks from electric trams, brightly lit windows, neon advertising signs, and the red warning lights of radio station antennas. The family has walked out onto open scaffolding prepared for the building of an addition to the supermarket. The fantasy comes to its symmetrical and logical conclusion in the final image of the crane looming overhead with its open maw: "Era una bocca enorme, senza denti, che s'apriva protendendosi su un lungo collo metallico ... Calava su di loro, si fermava alla loro altezza, la ganascia inferiore contro il bordo dell'impalcatura" (112-113). This is a fantasy that Marcovaldo can understand, atavistically, effortlessly. He knows immediately what he must do. Sacrifice, propitiation to the ravenous, demanding god is carried out silently, with neither hesitation nor instruction to the other family members. Marcovaldo approaches the gaping mouth, empties his cart into it, and as each other family member empties his own cart into the awaiting jaws and passes on in turn, there remains only an ironic reminder of Marcovaldo's problematic place in the urban universe, "le scritte luminose multicolori che invitavano a comprare prodotti in vendita nel grande supermarket" (113).

"Il coniglio velenoso" and "La fermata sbagliata" illustrate variations of the same procedure. In the first of these two stories, the frowsty, antiseptic smell of the hospital ward, the bars of the hospital bed, like the lights and sounds of the unattainable outside world, trigger Marcovaldo's double fantasy when he discovers the caged laboratory rabbit: "E lo guardava con l'occhio amoroso dell'allevatore che riesce a far coesistere la bontà verso l'animale e la previsione dell'arrosto nello stesso moto dell'animo" (70-71). A pellucid fantasy then takes over Marcovaldo's mind; "gli umidi muri di casa sparivano e c'era una fattoria verde tra i campi" (72), only to dissolve again swiftly after the escape of the rabbit. Its freedom is short-lived, as is Marcovaldo's vision, both abruptly truncated by an oppressive and pitiless society that prompts Calvino to write in these last two pages of the episode the harshest passage of the book (78-79). Just as the rabbit is frustrated in its attempt to die rather than face capture, and is scooped up to be returned to its cage, Marcovaldo is caught in the same gloved and sterile hands of the institutional numen, his fate, too, at the mercy of these impersonal gods of the city.

Another of Marcovaldo's sources of evasion is the fantasy afforded him by the large screen films in color at the cinema, "che permette d'abbracciare i più 
vasti orizzonti: prateric, montagne rocciose, foreste equatoriali, isole dove si vive coronati di fiori" $(80)$. This most familiar modern form of escape, the subject of "La fermati sbagliata," is introduced as the antidote "per chi ha in uggia la casa inospitale" (80), and fulfills Marcovaldo's need, except on this particular night when the cold, grey drizzle, the dense fog, and the depressing thought that he will never really experience these wonders cause the splendor of the film's images to fade abruptly and lose their power. Almost simultaneously, however, the dense fog that fills the streets begins to cancel out all signs of the external world and Marcovaldo is enveloped in a second, unexpected fantasy of liberation. The fog is a protective blanket around him; he is prey to no external stimulus and he can literally dream with his eyes wide open and project anew the desired images of the film he has just seen, "che ... si svolgeva nelle foreste dell'India: dal sottobosco paludoso s'alzavano nuvole di vapori, e i serpenti salivano per le liane c s'arrampicavano alle statue d'antichi templi inghiottiti dalla giungla" (80). He moves through unrecognizable streets, wanders into a café, then back out into the streets and finally to an entirely unfamiliar cityscape. Here he is confronted with total disorientation in a transformational passage through a world much like that of the unfamiliar maze of aisles of the supermarket or that of the enclosed and concentrated signs of suffering that he sees in the hospital where he is equally depressed and frustrated by "la nebbia che c'era fuori e che dava l'idea di doversene uscire nel vuoto, di sfarsi in un umido niente" (70). The hovering threat of annihilation is ever present for Marcovaldo. When he finds himself aboard an airplane, instead of a city bus, and bound for Bombay, Calcutta, and Singapore, all the exotic and mysterious places suggested to him by the film, the transformation is complete. Marcovaldo, and Calvino, have been borne aloft by a modern Pegasus but, unlike Calvino, Marcovaldo is also its captive.

$\mathrm{He}$ is also captive to an historical ideal gone sour. His lack of success in his vain search for identification with a nature that no longer exists for him (and Calvino suggests ironically that it probably never did) is expressed thematically in each of the episodes through the tension, the opposition of his desires, and the wretchedness of his daily existence. Even his eldest son, Michelino, echoes Calvino's cynical attitude toward the idea of a lost pastoral and idyllic existence when he returns home after a stint of summer work as a cowherd ("Un viaggio con le mucche"). Marcovaldo envisions his son's enjoyment and envies him this time spent in the mountains, in the open air, far from the invasive and unpleasant city sounds, "I'anonimo frastuono dei motori," "un russare dai piani di sopra," "l'orchestra delle sveglie nelle case operaie" (63). Michelino, however, destroys his father's fantasy almost immediately when he pungently complains of the long hours of hard work and low wages, adding that he has no intention of giving any of his meager earnings to his father. The rubrical categories of five series of seasonal stories are an ironic formal frame for this element of Marcovaldo's imagined odyssey, 
as the herd now continues to move off through the streets, "portandosi dietro i menzogneri e languidi odori di fieno e suoni di campani” (68). Even the implication of repetition of nature's cycles affords only the slightest touch of optimism.

The search for identification with history is even more perfunctory, emblematized in the nugatory appearance of another set of even more pointedly ironic rubrics: the names assigned to almost all the characters, from Marcovaldo and Domitilla to those who appear only once in a single episode. They bear proud, high-born but anachronistic names that should evoke images of chivalric exploit and romance, mediaeval bravery and heraldic blazons. Instead, la signora Diomira, the neighbor, is known for her talent at killing and skinning animals for the pot; il cavalier Ulrico, vecchio cacciatore, is the tenement sharpshooter; Sigismondo is a disoccupato; Guendalina, a washerwoman; Tornaquinci, il vigile notturno. Similarly, Amadigi, Astolfo, Fiordaligi, il signor Viligelmo, and il dottor Godifredo, these last two who hold the exalted position of caporeparto and agente di pubblicita luminosa, respectively. Their names are all that remains of an heroic and idealized dream. The desperation of Marcovaldo's defeat is glossed over through the expedient of madcap and bumbling high jinks when nature refuses to respond gently to his muted entreaties. History responds out of the side of its mouth, with a satiric intonation of distortion in its enunciation of ill-fitting labels. Marcovaldo's children (Michelino, Pietruccio, Filippetto, Isolina and Teresina) and even the young son of the wealthy family in "I figli di Babbo Natale," Gianfranco, are the only ones to escape such anomalous names, offering another small and benignly optimistic contrast to their elders. They may have a better chance to pen the outlines of their own fate on the blank page.

Calvino's anti-theoretical attitude is another constant which took two complementary forms throughout his career: first, a consistent rejection of the efficacy of any and all contemporary comprehensive "theories" of literature that dates from the time of his early essays; and, second, the specifically critical thrust of all his metanovelistic narratives and several among his eristic introductions to those narratives (notably, Le città invisibili, Se una notte d'inverno un viaggiatore and the introduction to I nostri antenati). ${ }^{4}$ The Marcovaldo introduction situates itself in this context both as precursor to Calvino's antideconstructivism and as example of a simplified statement of the several levels at which the narrative may function simultaneously, in this particular case, in the guise of explication to a "young" audience, determined by the specific edition of the work. ${ }^{5}$ The ironic prefatory note to the introduction immediately elevates the prospective readers' acumen above professorial humbuggism and need for a prepared textual explication: "Prefazione un po" seria e un po' noiosa d'un libro che non vuol essere tale, ragione per cui i nostri lettori possono benissimo saltarla (ma se qualche professore volesse leggerla, vi troverà alcune istruzioni per l'uso)" (5). Particularly in the ear- 
lier part of his career, Calvino rarely passed up an opportunity for a gentle nose-thumbing at the critics.

Suteliffe points out that even more than Borges and Pynchon, Calvino's fiction invites the attention of literary theorists, whose language he often spoke and whose preoccupations he always shared. Several of these preoccupations are already manifest in this early work. "Luna e Gnac" in its intricacy of semiotic symbolism and, at the same time, in its simplicity of presentation immediately invites such attention. Another of the stories equally concerned with these same issues has received, however, minimal mention. "La città smarrita nella neve" posits a particular aspect of the relationship between the written and the unwritten world, between the ordered reality of the fixed, opaque landscape of the city and the possibilities for reshaping it according to the needs of the imagination. A blanket of new snow has obliterated all sign of the city's outlines, all concrete objects. For the first time Marcovaldo "era diventato padrone di camminare in mezzo alla strada, di calpestare le aiuole, d'attraversare fuori delle linee prescritte, di avanzare a zig-zag" (32). The city may well have become a different and freer place, and Marcovaldo daydreams of losing himself within it, anticipating the significance of the simile of the blank page which appears in the last paragraph of "I figli di Babbo Natale" as the final invitation to uncertainty for both writer and reader: "Si vedeva solo la distesa di neve bianca come questa pagina" (148). However, habit, the nemesis of creativity, guides his steps to his workplace. The barrier represented by familiarity is for the moment stronger than the imagination, although Marcovaldo, spurred on by his immediate fantasy, does take up his shovel almost willingly: "Spalar neve non è un gioco, specie per chi si trova a stomaco leggero, ma Marcovaldo sentiva la neve come amica, come un elemento che annullava la gabbia di muri in cui era imprigionata la sua vita" (33). The blanket of snow serves the same function as the fog in "La fermata sbagliata" to predictably provoke the transformational fantasy. From his vague wish to erase the configuration of the city as he knows it, Marcovaldo's first desire for escape and evasion gives way to the more critically inventive urge to recreate, refashion the city - to rewrite the world as he would have it. "Rifare la città, ammucchiare montagne alte come case, che nessuno avrebbe potuto distinguere dalle case vere. O forse ormai tutte le case erano diventate di neve, dentro e fuori; tutta una città di neve con $i$ monumenti e i campanili e gli alberi, una città che si poteva disfare a colpi di pala e rifarla in un altro modo" (34-35). The possibilities for rewriting the world are infinite. Marcovaldo not only refashions the city, he becomes a part of it, one of his creations, as a mountain of cascading snow from the rooftops falls down upon him and gives him the contours of a nearby snowman made by a group of children. He is suborned momentarily and given new outlines as an integral part of a candid, refreshed world but only momentarily. His sneeze, precipitating a whirlwind that sucks up every flake of snow and draws it skyward, leaves Marcovaldo in the drab, familiar courtyard with its hostile, 
sharp corners and grey walls, his brief moment of creativity ended. But he has had a moment.

In addition to his theorizing comments in the introduction to Marcovaldo, Calvino further invites theoretical attention through the changing levels of symbolism of the various stories, through playful experimentation with the comic and maladroit anti-hero ("l'ultima incarnazione di una serie di candidi eroi poveri-diavoli alla Charlie Chaplin" [5]) who is a new phenomenon in Italian literature, in the still little cultivated fictional sub-genre of humorous fiction, and, finally, in the implication that Marcovaldo's significance goes far beyond the befuddled and awkward gestures which express his rough grasp of the world that presses in around him. Marcovaldo is a comprehensive symbol of a newer form taken by the lower class. As a class, it is inchoate, as defenseless - and as indestructible - as century-old generations of its hinterland counterparts who were finally given first voice and substance by Verga eighty years earlier. Other more recent and expanded literary echoes of that voice also resound, through the choruses of the poor in novels from Federigo Tozzi and Corrado Alvaro to Carlo Levi and Ignazio Silone. Alberto Moravia's thesis appears as a coda, in his numerous essays, perhaps most succinctly in "L'uomo come fine," written in 1946, and in the later essay, "I miei problemi," of 1962. These essays serve as counterpoint to Calvino's Marcovaldo introduction. The rampant Machiavellianism that Moravia decries as late as the early 1960's in open and direct polemic demonstrates the intensity of the Neo-Realist ethic that still retained critical viability: "Il mondo moderno è convinto che soffrire sia esistere, che il dolore sia la prima e ultima prova dell'esistenza, come incapacità. Ma questo si otterrà soltanto strappando l'uomo al suo presente impiego di mezzo e restaurando la sua natura di fine" (239). Marcovaldo's alienation is of this same order. ${ }^{6}$

It is, however, an alienation of a completely different stamp. The violence of historical and sociological realities is masked and swathed in layers of comic padding. Only rarely does the starkness of the lonely and desperate struggle for survival emerge in the foreground, as in the single third paragraph of the first story, "Funghi in città" (15); in the transparent allegorical tale of the hare and the wolf that comprises the seven short paragraphs at the end of the last story, "I figli di Babbo Natale" (148); and in the infected rabbit's resignation to death, in "ll coniglio velenoso" (78). Situated between these are the ill-coordinated and nervously darting movements of Marcovaldo and the ebullient caprioles of his children. Domitilla adds her hectoring comments as a running dose of domestic gloom, while the daughters appear only infrequently and statically to play out their stereotyped ingenuousness and, in the case of Isolina, adolescent and romantic dreaming. All resemble familiar stock characters acting out their assigned roles through a succession of romps and capers, lazzi and doti, in a commedia dell'arte scenario. It is their presence as family members that fleshes out their identity and captivates the reader with simple domestic truths purveyed most often by the children, 
while it underlines the heavy hurdens and responsibilities of Marcovaldo.

In one sense, Marcovalde is a "fable for our limes" in the manner of James Thurber, as it focuses alternately on Marcovaldo and his children, setting the experiences of the two succeding generations against each other in its series of bemused and often pathetic episodes. Each contains a fantasy of desire and defeat, and a final transformation of the fantasy that raises it to levels above and beyond the hallucinatory mechanisms of the industrial metropolis. The written world lies heavily below in the arena of the large city, fixed in its human records of urban progress and decay. If Calvino accepts the written reality of the city in its historical function and its inspirational power in the modern world, he also demands that the silences of all the unwritten records be given their vital living space, as well. It is ultimately, and not surprisingly, natural phenomena-drizzling rain, fog, and snowthat Calvino chooses to introduce his paradoxical images and signal these moments of quiescence. The winter snow, particularly, emerges as the most effective, most transparent symbol of these silences, of these pauses for the nurturing of undistracted imagination. It covers the city with a silent clarity, and appears finally in the countryside at the end of the last story, just as the wind had arrived from afar in the first story, levelling and smoothing over all the tracks that have ever been made before, to open the way for both the hare and the wolf to set out again and again across an eternally empty page.

\section{NOTES}

1 "I believe more and more in literature as a language that says things that other languages can't say, that literature has full status as a form of knowledge" (Stille 38).

2 "Aveva questo Marcovaldo un occhio poco adatto alla vita di città: cartelli, semafori, vetrine, insegne luminose, manifesti, per studiati che fossero a colpire l'attenzione, mai fermavano il suo sguardo che pareva scorrere sulle sabbie del deserto. Invece, una foglia che ingiallisse su un ramo, una piuma che si impigliasse ad una tegola, non gli sfuggivano mai: non c'era tafano sul dorso d'un cavallo, pertugio di tarlo in una tavola, buccia di fico spiaccicata sul marciapiede che Marcovaldo non notasse, $\mathrm{e}$ non facesse oggetto di ragionamento, scoprendo i mutamenti della sua esistenza" (Marcovaldo 15-16).

3 "There are moments when Marcovaldo as a character is not far from the famous (in ltaly) character of Sor Pampurio, a classic comic strip published many decades ago by the first national magazine of comics, /l corriere dei piccoli" (La Polla 40).

4 The introduction to I nostri antenati was written in June, 1960, and appeared in the first re-issue of the three novels of the trilogy (II isconte dimezato, 1952: II barone' rampante. 1957; and /l cavaliere inesistente, 1959) in a single volume bearing the new title.

5 "Libro per bambini? Libro per ragazzi? Libro per grandi? Abbiamo visto come tutti questi piani continuamente si intreccino. O piutlosto libro in cui l'Autore attraverso lo schermo di strutture semplicissime, esprime il proprio rapporto, perplesso e interrogativo, col mondo? Forse anche questo" (Marcovaldo 11 ).

6 Marcovaldo's ragged and constantly frustrated attempts to insert himself in a culture based on production and consumption exemplifies Moravia's earlier statement in the same essay: "Di conseguenza adoperare l'uomo come mezzo deriva dal non porsi l'uomo come fine ossia dal non avere rispetto dell'uomo, vale a dire dal non sapere che cosa sia l'uomo e dal non avere una chiara e sufficiente idea dell'uomo" (207). 


\section{WORKS CITED}

Brodsky, Joseph. Address. Nobel Prize. December 1987.

Calvino, Italo. I nostri antenati. Torino: Einaudi, 1960.

I racconi. Torino: Einaudi, 1958.

Marcovaldo ovvero le stagioni in città. Torino: Einaudi, 1966.

"The Written and the Unwritten Word." The James Lecture, presented on

March 30, 1983, at the New York Institute for the Humanities. The New York Review 12 May 1983: 38-39.

La Polla, Franco. “A Note on Marcovaldo." The Review of Contemporary Fiction 6.2 (1986): $38-41$.

Moravia, Alberto. L'uomo come fine e altri saggi. Milano: Bompiani, 1964.

Olken, 1. T. With Pleated Eye and Garnet Wing: Symmetries of Italo Calvino. Ann Arbor: U of Michigan P, 1984.

Stille, Alexander. "An Interview with Italo Calvino." Saturday Review Mar./Apr. 1985: 37-39. Sutcliffe, Thomas. "Before the Art of Cunning." Times Literary Supplement 2 Sept. 1983: 921. Vittorini, Elio. Diario in pubblico. Milano: Bompiani, 1957. 